\title{
STRATEGI PENGEMBANGAN INDUSTRI IKAN PINDANG \\ SKALA SEDANG DAN BESARDI KABUPATEN PATI
}

\author{
DEVELOPMENT STRATEGY FORMEDIUMAND \\ LARGE SCALE BOILED FISH INDUSTRIESIN PATI REGENCY
}

\author{
Herna Octivia Damayanti \\ Kantor Penelitian dan Pengembangan Kabupaten Pati \\ Email: octivia_oc@yahoo.co.id
}

Naskah Masuk: 21 September 2015 Naskah Revisi: 5 Oktober 2015 Naskah Diterima: 12 Oktober 2015

\begin{abstract}
Processed form of marine fisheries that quite popular in Pati regency is boiled fish. The medium and large scale boiled fish industry can accelerate the growth of fishery and marine sector. The purpose of study is to formulate alternative strategies for developing medium and large scale boiled fish industries in Pati regency. The research used quantitative descriptive method and was condusted in March 2014. Primary data were obtained through interview with medium and large scale boiled fish employers, while secondary data were derived from relevant documents from marine and fisheries agency of Pati regency. Respondents were chosen using purposive sampling. Data were analyzed using SWOT and QSPM. Results of the research showed that the first priority strategy was improving the performance of association of boiled fish employers so it can be made a common agreement on the business management system and the boiled fish industry standard marketable products, with TAS value 4.948 .
\end{abstract}

Keywords : boiled fish, medium scale industry, large scale industry, strategy

\begin{abstract}
ABSTRAK
Bentuk olahan hasil perikanan laut yang cukup populer di Kabupaten Pati adalah ikan pindang. Industri ikan pindang skala sedang dan besar dapat mempercepat pertumbuhan ekonomi dari sektor perikanan dan kelautan. Tujuan penelitian ini adalah untuk merumuskan alternatif strategi untuk pengembangan industri ikan pindang skala sedang dan besar di Kabupaten Pati. Penelitian ini menggunakan metode deskriptif kuantitatif dan dilaksanakan pada bulan Maret 2014. Sumber data primer yang diperoleh melalui wawancara dengan pengusaha pemindangan ikan skala sedang dan besar. Sedangkan data sekunder berasal dari dokumen relevan Dislautkan Kab. Pati. Metode pemilihan sampel responden dengan pendekatan purposive sampling. Analisis data dilakukan dengan analisis SWOT dan untuk menentukan prioritas strategi menggunakan analisis QSPM. Hasil penelitian yaitu prioritas strategi pertama adalah peningkatan kinerja wadah perhimpunan pengusaha ikan pindang sehingga dapat dibuat kesepakatan bersama tentang sistem manajemen usaha industri ikan pindang dan standar produk yang layak jual, dengan nilai TAS 4,948.
\end{abstract}

Kata kunci : ikan pindang, industri skala sedang, industri skala besar, strategi 


\section{PENDAHULUAN}

Hasil perikanan tangkap di Kabupaten Pati tidak hanya dijual dalam bentuk segar, tetapi juga dilakukan pengolahan. Bentuk olahan hasil perikanan tangkap yang cukup populer dan banyak diusahakan di Kabupaten Pati salah satunya adalah ikan pindang. Jumlah industri pemindangan ikan di Kabupaten Pati adalah 104 industri yang terdiri dari 83 industri ikan pindang dan 21 industri bandeng presto. Industri pemindangan ikan ini terdiri dari berbagai skala yaitu rumah tangga, kecil, sedang dan besar (Dislautkan Kab. Pati, 2014).

Industri pengolahan hasil perikanan tangkap yang berupa industri ikan pindang di Kabupaten Pati terdapat dalam berbagai skala industri yaitu rumah tangga, kecil, sedang dan besar. Industri yang mampu menyerap tenaga kerja dalam jumlah besar yaitu industri dengan skala sedang dan besar. Industri besar jumlah tenaga kerja 100 orang atau lebih; industri sedang jumlah tenaga kerja 20 orang sampai dengan 99 orang (BPS Prov. Jateng, 2013).

Selain mampu menyerap tenaga kerja dalam jumlah besar, skala industri sedang dan besar juga memiliki kapasitas produksi yang besar. Untuk industri ikan pindang skala sedang dan besar berkisar antara ratusan kilogram hingga puluhan ton per hari, sedangkan industri rumah tangga dan kecil hanya mampu memproduksi hingga puluhan kilogram saja (Dislautkan Kab. Pati, 2014). Berdasarkan data Dislautkan Kab. Pati (2014) bahwa potensi paling besar pengolahan hasil perikanan tangkap untuk industri ikan pindang berada pada industri skala sedang dan besar karena wilayah pemasaran yang mampu menembus wilayah diluar Kabupaten Pati.

Potensi pengolahan hasil perikanan yang sangat besar dari industri ikan pindang skala sedang dan besar ini selaras dengan program Kementerian Kelautan dan Perikanan Republik Indonesia. KKP sejak tahun 2012 mengembangkan industrialisasi kelautan dan perikanan dengan tujuan untuk meningkatkan kontribusi sektor kelautan dan perikanan terhadap pertumbuhan ekonomi dan meningkatkan kesejahteraan rakyat (KKP, 2012). Cara untuk mempercepat pertumbuhan ekonomi dari sektor perikanan dan kelautan melalui pengembangan industriindustri pengolahan ikan potensial seperti industri ikan pindang skala sedang dan besar.

Berdasarkan latar belakang tersebut, maka tujuan penelitian ini adalah untuk merumuskan alternatif strategi untukpengembangan industri ikan pindang skala sedang dan besar di Kabupaten Pati.

\section{TINJAUAN PUSTAKA}

\section{Industri}

Industri adalah kegiatan
memproses atau mengolah barang dengan menggunakan sarana dan peralatan, misal mesin (KBBI, 2014). Menurut BPS, sektor industri dibedakan menjadi industri besar, industri sedang, industri kecil, dan industri rumah tangga (BPS Prov. Jateng, 2013). Klasifikasi skala industri sebagai berikut :

a. Industri besar adalah perusahaan yang mempunyai tenaga kerja 100 orang atau lebih.

b. Industri sedang adalah perusahaan dengan tenaga kerja 20 orang sampai dengan 99 orang. 
c. Industri kecil adalah perusahaan dengan tenaga kerja 5 orang sampai dengan 19 orang.

d. Industri rumah tangga adalah perusahaan dengan tenaga kerja 1 orang sampai dengan 4 orang.

\section{Industri Ikan Pindang Di Kabupaten Pati}

Jumlah industri pemindangan ikan di Kabupaten Pati adalah 104 industri yang terdiri dari 83 industri ikan pindang dan 21 industri bandeng presto (Dislautkan Kab. Pati, 2014).

Untuk Industri ikan pindang, skala industri sedang dan besar berjumlah 30 industri dan industri ikan pindang skala rumah tangga dan kecil berjumlah 53 industri. Industri ikan pindang skala sedang dan besar berada di Kecamatan Juwana, sedangkan industri ikan pindang skala rumah tangga dan kecil berada di Kecamatan Juwana, Dukuhseti, Tayu, Margoyoso, Wedarijaksa, Pati dan Jakenan (Dislautkan Kab. Pati, 2014).

\section{METODE PENELITIAN}

Penelitian ini menggunakan metode deskriptif kuantitatif dan dilaksanakan pada bulan Maret 2014. Sumber data berupa data primer yang diperoleh dari wawancara dengan pengusaha pemindangan ikan skala sedang dan besar. Sedangkan data sekunder berasal dari dokumen relevan Dislautkan Kab. Pati.

Metode yang digunakan dalam pengambilan sampel responden adalah purposive sampling. Responden penelitian merupakan pengusaha ikan pindang skala sedang dan besar. Lokasi penelitian berada di Desa Dukutalit dan Desa Bajomulyo Kecamatan Juwana.

Analisis data dengan menggunakan SWOT untuk merumuskan alternatif strategi (Rangkuti, 1999).
Sedangkan untuk menentukan prioritas strategi yang direkomendasikan menggunakan QSPM(David, 2009).

\section{HASIL DAN PEMBAHASAN}

\section{Faktor Strategis Internal Dan Eksternal}

Hasil skoring faktor internal dibuat dalam matriks Evaluasi Faktor Internal (IFE) disajikan pada Tabel 1.

Kekuatan dominan dari faktor internal yaitu transportasi untuk pemasaran mudah, sumber daya manusia pengelola industri ikan pindang sudah profesional dan modal usaha mencukupi. Ketiga kekuatan ini menjadi kekuatan dominan karena memiliki bobot diatas 0,1 .Wahyudi $d k k$ (2012) menyatakan bahwa jika nilai pembobotan diatas 0,1 menunjukkan faktor tersebut memiliki peranan yang dominan. Transportasi yang mudah menjadikan proses pemasaran produk ikan pindang menjadi lancar. Untuk industri ikan pindang dengan skala sedang dan besar sudah memiliki armada transportasi sendiri yaitu jenis colt atau truk sehingga dapat mengatur jadwal pengiriman produk kepada pemesan sesuai dengan kesepakatan. Selain itu, manajemen pengelolaannya sudah tertata dengan baik dan setiap orang mempunyai peranan masing-masing (sudah ada pembagian tugas). Dukungan modal usaha yang cukup memungkinkan industri ikan pindang skala sedang dan besar untuk memproduksi ikan pindang dalam jumlah besar (sehari produksi mampu mencapai hitungan ton). Modal yang cukup juga membuat pengusaha ikan pindang mampu mempekerjakan tenaga kerja dalam jumlah besar untuk mendukung kegiatan produksinya.

Kelemahan dominan dari faktor internal yaitu peralatan produksi masih sederhana, belum ada standar kebersihan 
dalam proses produksi dan umur penyimpanan produk relatif singkat. Peralatan produksi yang masih sederhana menjadikan proses produksi kurang efisien dan membutuhkan tenaga kerja dalam jumlah besar karena masih dikerjakan secara manual. Proses produksi yang masih dilakukan secara manual menjadikan kurang terjaganya kebersihan selama proses produksi. Hal ini terjadi karena banyak melibatkan orang banyak dan belum adanya standar yang ditetapkan oleh pabrik itu sendiri. Salah satu kendala terbesar produk ikan pindang adalah umur penyimpanan produk relatif singkat. Produk ikan pindang yang diolah dengan cara perebusan menjadikan produk banyak mengandung air sehingga mudah tumbuh bakteri dan produk menjadi cepat busuk.

Tabel 1.

Matriks Evaluasi Faktor Internal (IFE)

Industri Pemindangan Ikan Skala Sedang dan Besar

\section{Faktor-faktor Strategi Internal}

\begin{tabular}{|c|c|c|c|c|}
\hline \multicolumn{2}{|c|}{ Kekuatan/Strength } & Bobot & Rating & Skor \\
\hline 1 & Produk sudah dikenal & 0,088 & 3 & 0,265 \\
\hline 2 & Transportasi untuk pemasaran mudah & 0,146 & 4 & 0,584 \\
\hline 3 & $\begin{array}{l}\text { Sumber daya manusia pengelola industri ikan pindang sudah } \\
\text { profesional }\end{array}$ & 0,129 & 4 & 0,515 \\
\hline \multirow[t]{2}{*}{4} & Modal usaha mencukupi & 0,124 & 4 & 0,442 \\
\hline & Total Kekuatan & & & 1,806 \\
\hline \multicolumn{5}{|c|}{ Kelemahan/Weaknesses } \\
\hline 1 & Peralatan produksi masih sederhana & 0,133 & 2 & 0,265 \\
\hline 2 & Belum ada standar kebersihan dalam proses produksi & 0,181 & 1 & 0,259 \\
\hline 3 & $\begin{array}{l}\text { Belum ada standar komposisi bahan tambahan dalam proses } \\
\text { produksi }\end{array}$ & 0,071 & 2 & 0,142 \\
\hline \multirow[t]{4}{*}{4} & umur penyimpanan produk relatif singkat & 0,129 & 2 & 0,257 \\
\hline & Total Kelemahan & & & $\mathbf{0 , 9 2 3}$ \\
\hline & Selisih Total Kekuatan-Total Kelemahan & & & $\mathbf{0 , 8 8 3}$ \\
\hline & Total IFE & & & 2,728 \\
\hline
\end{tabular}

Sumber : Pengolahan data, 2014

Hasil skoring faktor eksternal dibuat dalam matriks Evaluasi Faktor Enternal (EFE) disajikan Tabel 2.

Peluang dominan dari faktor eksternal yaitu wilayah pemasaran luas, nilai jual terjangkau semua lapisan masyarakat dan produk diminati semua lapisan masyarakat. Peluang mendirikan industri ikan pindang adalah semua lapisan masyarakat mengenal dan menyukai ikan pindang. Hal ini menjadikan pangsa pasar ikan pindang sangat luas baik untuk kalangan ekonomi bawah, menengah sampai atas mengkonsumsi ikan pindang. Selain itu, harga jual ikan pindang terjangkau semua lapisan masyarakat yaitu antara Rp. 2.000,- sampai Rp. 5.000,tergantung dari ukuran ikan dalam tiap besek. Selain itu, isi dalam satu besek berjumlah 2 sampai 5 ekor sehingga mencukupi untuk konsumsi keluarga.

Ancaman dominan dari faktor eksternal yaitu pesaing dari daerah lain 
dan penguasaan teknologi dan pengetahuan terbaru tentang ikan pindang masih kurang. Banyaknya pesaing dari daerah lain menjadikan terjadinya persaingan untuk merebut pasar. Cara yang dapat dilakukan untuk tetap mempertahankan eksistensi para pengusaha ikan pindang yaitu dengan berupaya mempertahankan bakul pemesan dan menjaga stabilitas harga jual dari pengusaha ke bakul sehingga bakul tidak akan lari mencari pengusaha lain yang menawarkan harga lebih rendah. Selain persaingan dengan pengusaha lain, ancaman yang harus dihadapi pengusaha ikan pindang adalah penguasaan teknologi ynag masih sederhana. Teknologi produksi yang msih sederhana dan manual membutuhkan tenaga kerja dalam jumlah besar dan kurang efisien sehingga biaya produksi menjadi besar. Hal ini dapat menyebabkan kerugian bagi pengusaha ikan pindang jika harga-harga bahan baku dan bahan-bahan pendukung produksi mengalami kenaikan tetapi harga jual produk yang diminta bakul pemesan tetap sama karena biaya produksi menjadi lebih besar dibanding pendapatan yang diperoleh.

Tabel 2.

Matriks Evaluasi Faktor Eksternal (EFE)

Industri Pemindangan Ikan Skala Sedang dan Besar

\begin{tabular}{|c|c|c|c|}
\hline Faktor-faktor Strategi Eksternal & \multirow{2}{*}{ Bobot } & \multirow{2}{*}{ Rating } & \multirow{2}{*}{ Skor } \\
\hline Peluang/Opportunities & & & \\
\hline $\begin{array}{l}\text { Program industrialisasi kelautan dan perikanan melalui } \\
\text { pendekatan blue economy }\end{array}$ & 0,071 & 3 & 0,223 \\
\hline 2 Wilayah pemasaran luas & 0,177 & 4 & 0,708 \\
\hline 3 Nilai jual terjangkau semua lapisan masyarakat & 0,133 & 4 & 0,531 \\
\hline 4 Produk diminati semua lapisan masyarakat & 0,124 & 4 & 0,495 \\
\hline Total Peluang & & & 1,957 \\
\hline \multicolumn{4}{|l|}{ Ancaman/Threat } \\
\hline $\begin{array}{ll}1 & \text { Pesaing dari daerah lain }\end{array}$ & 0,159 & 2 & 0,318 \\
\hline 2 Bahan baku kurang mencukupi/kurang memadai & 0,089 & 2 & 0,139 \\
\hline $\begin{array}{l}3 \text { Peran perhimpunan pengusaha pindang belum berjalan } \\
\text { secara optimal }\end{array}$ & 0,159 & 2 & 0,319 \\
\hline 4 Sistem talangan dalam penjualan (pemesanan) produk & 0,088 & 2 & 0,177 \\
\hline Total Ancaman & & & $\mathbf{0 , 9 5 3}$ \\
\hline Selisih Total Peluang-Total Ancaman & & & $\overline{1,004}$ \\
\hline Total EFE & & & $\overline{2,910}$ \\
\hline
\end{tabular}

Sumber : Pengolahan data, 2014 


\section{Formulasi Alternatif Strategi}

Matriks SWOT menggunakan faktor internal dan eksternal sebagai dasar untuk menghasilkan strategi- strategi yang layak untuk dipertimbangkan (David et al., 2009).

Alternatif strategi yang dihasilkan disajikan pada Tabel 3.

Tabel 3.

Matriks SWOT Industri Pemindangan Ikan Skala Sedang dan Besar

\begin{tabular}{|c|c|c|}
\hline \multirow{2}{*}{$\begin{array}{l}\text { FAKTOR INTERNAL DAN } \\
\text { EKSTERNAL }\end{array}$} & KEKUATAN/STRENGTH & KELEMAHAN/WEAKNESS \\
\hline & $\begin{array}{l}\text { 1. Produk sudah dikenal } \\
\text { 2. Transportasi untuk } \\
\text { pemasaran mudah } \\
\text { 3. Sumber daya manusia } \\
\text { pengelola industri ikan } \\
\text { pindang sudah profesional } \\
\text { 4. Modal usaha mencukpi }\end{array}$ & $\begin{array}{l}\text { 1. Peralatan produksi masih } \\
\text { sederhana } \\
\text { 2. Belum ada standar } \\
\text { kebersihan dalam proses } \\
\text { produksi } \\
\text { 3. Belum ada standar } \\
\text { komposisi bahan tambahan } \\
\text { dalam proses produksi } \\
\text { 4. Umur penyimpanan produk } \\
\text { relatif singkat }\end{array}$ \\
\hline PELUANG/OPPORTUNITY) & STRATEGI S-O & STRATEGI W-O \\
\hline $\begin{array}{l}\text { 1. Program industrialisasi } \\
\text { kelautan dan perikanan } \\
\text { melalui pendekatan blue } \\
\text { economy } \\
\text { 2. Wilayah pemasaran luas } \\
\text { 3. Nilai jual terjangkau semua } \\
\text { lapisan masyarakat } \\
\text { 4. Produk diminati semua } \\
\text { lapisan masyarakat }\end{array}$ & $\begin{array}{l}\text { Perluasan jaringan pemasaran } \\
\text { melalui perantara bakul } \\
\text { langganan untuk melakukan } \\
\text { promosi kepada bakul-bakul } \\
\text { lain } \\
\text { Penetrasi produk ikan pindang } \\
\text { ke pasar-pasar modern untuk } \\
\text { produk ikan pindang yang mutu } \\
\text { dan kualitasnya bagus }\end{array}$ & $\begin{array}{l}\text { Peningkatan kualitas produk } \\
\text { ikan pindang dengan penerapan } \\
\text { standar kebersihan dan standar } \\
\text { mutu produk }\end{array}$ \\
\hline ANCAMAN/THREAT & STRATEGI S-T & STRATEGI W-T \\
\hline $\begin{array}{l}\text { 1. Pesaing dari daerah lain } \\
\text { 2. } \begin{array}{l}\text { Bahan baku kurang } \\
\text { mencukupi/kurang } \\
\text { memadai }\end{array} \\
\text { 3. Peran perhimpunan } \\
\text { pengusaha pindang belum } \\
\text { berjalan secara optimal } \\
\text { 4. Sistem talangan dalam } \\
\text { penjualan (pemesanan) } \\
\text { produk }\end{array}$ & $\begin{array}{l}\text { Penerapan sistem manajemen } \\
\text { modern pada industri ikan } \\
\text { pindang dengan peningkatan } \\
\text { profesionalitas kerja, } \\
\text { penguasaan teknologi dan } \\
\text { pengetahuan baru, pembenahan } \\
\text { tata cara pemasaran, penjualan } \\
\text { produk dan pengelolaan } \\
\text { keuangan }\end{array}$ & $\begin{array}{l}\text { Peningkatan kinerja wadah } \\
\text { perhimpunan pengusaha ikan } \\
\text { pindang sehingga dapat dibuat } \\
\text { kesepakatan bersama tentang } \\
\text { sistem manajemen usaha } \\
\text { industri ikan pindang dan } \\
\text { standar produk yang layak jual }\end{array}$ \\
\hline
\end{tabular}

Sumber : Pengolahan data, 2014

Strategi SO-1 yang dihasilkan yaitu perluasan jaringan pemasaran melalui perantara bakul langganan untuk melakukan promosi kepada bakul-bakul lain. Industri skala sedang dan besar dalam menjalankan kegiatan produksi maupun operasional sudah tergolong stabil. Hal ini karena dukungan dari manajemen pengelolaan yang sudah tertata dan modal usaha yang mencukupi.Dengan demikian, hal yang harus dilakukan untuk tetap menjaga keberlangsungan industri ini adalah dengan merupaya memperluas jaringan 
pemasaran produknya (dalam hal ini adalah upaya memperbesar profit usaha yang didapat). Cara paling mudaha yang dapat dilakukan yaitu dengan perantara bakul langganan karena bakul langganan ini secara tidak langsung akan menjual nama dan produk yang dihasilkan sebuah industri. Selain itu, bakul langganan ini semestinya mengenal bakul-bakul lain sehingga dengan bantuan dari bakul langganan akan lebih mudah mempromosikan produk yang dihasilkan.

Strategi SO-2 yaitu penetrasi produk ikan pindang ke pasar-pasar modern untuk produk ikan pindang yang mutu dan kualitasnya bagus.Sejauh ini, produk ikan pindang baru dipasarkan di pasar-pasar tradisional.Bagi kalangan kelas ekonomi menengah ke atas yang cenderung lebih memilih untuk membeli kebutuhan kesehariannya di pasar-pasar modern (semacam minimarket dan supermarket), produk ikan pindang tidak dapat ditemukan di pasar-pasar tersebut.Kenyataan yang demikian tentunya dapat membuka peluang pemasaran produk ikan pindang yang lebih luas.Permasalahan yang dihadapi yaitu produk ikan pindang memiliki daya simpan yang relatif singkat dan belum memiliki standar kualitas sehingga sulit untuk dapat memasuki pasar modern.Cara yang dapat dilakukan untuk sedikit memperpanjang daya simpan ikan pindang yaitu dengan mengganti kemasan produk dengan plastik kedap udara dan melakukan pembekuan sehingga dapat menekan pertumbuhan bakteri yang menyebabkan pembusukan ikan pindang.

Strategi WO yaitu peningkatan kualitas produk ikan pindang dengan penerapan standar kebersihan dan standar mutu produk.Selain peningkatan daya simpan produk ikan pindang, peningkatan kualitas produk ikan pindang sangat penting untuk dilakukan.
Sejauh ini, belum ada standar yang diterapkan dalam proses produksi ikan pindang sehingga tidak diketahui secara pasti tingkat kebersihan produk yang dihasilkan. Standar kebersihan yang dipakai selama ini yaitu jika ikan pindang secara kasat mata terlihat bersih maka dianggap sudah memenuhi standar kebersihan, tanpa ada pengecekan secara detail untuk setiap tahap produksi yang dilakukan misalnya kebersihan bahan baku dan bahan tambahan, tempat pemilahan, besek ikan, tempat perebusan maupun dari pelaku produksinya (tenaga kerja). Mutu produk juga belum terkontrol, hal ini karena belum ada komposisi pasti bahan tambahan yang digunakan (hanya berdasarkan naluri dan kebiasaan) sehingga produk yang dihasilkan belum memiliki keseragaman rasa.Produk yang dihasilkan juga belum dipilah antara ikan pindang yang masih utuh dan tidak utuh (semua dianggap seragam).Penerapan standar kebersihan dan mutu sangat penting dilakukan untuk memperluas jaringan pemasaran terutama untuk kalangan ekonomi atas.

Strategi ST yaitu penerapan sistem manajemen modern pada industri ikan pindang dengan peningkatan profesionalitas kerja, penguasaan teknologi dan pengetahuan baru, pembenahan tata cara pemasaran, penjualan produk dan pengelolaan keuangan. Industri ikan pindang yang sudah berskala sedang dan besar harus terus membenahi sistem menejerialnya. Pembenahan-pembenahan ini dimaksudkan untuk mengikuti perkembangan usahanya karena dengan usaha yang terus berkembang maka dibutuhkan perubahan-perubahan dalam pengelolaan usaha, misalnya pemilihan 
dan penempatan tenaga kerja sesuai dengan kemampuan dan ketrampilan masing-masing, berupaya memperbaharui cara produksi untuk mengikuti perkembangan teknologi terbaru, pembenahan tata cara pemasaran dengan mulai menerapkan sistem kontrak kerja untuk mengurangi kerugian sebagai akibat sistem talangan dalam penjualan produk, dan sistem pembukuan keuangan yang lebih modern dengan penerapan teknologi dalam pengelolaannya (sistem komputerisasi).

Strategi WT yaitu peningkatan kinerja wadah perhimpunan pengusaha ikan pindang sehingga dapat dibuat kesepakatan bersama tentang pengelolaan usaha industri ikan pindang dan standar produk yang layak jual. Peningkatan kinerja wadah perhimpunan pengusaha ikan pindang adalah untuk melakukan penataan dan pengawasan terutama dalam hal pembagian bahan baku ikan dan sistem pembayaran penjualan produk. Selain itu, keberadaan wadah perhimpunan diharapkan dapat membuat sebuah kesepakatan tentang satandarisasi produk sehingga dapat menjamin kualitas produk ikan pindang yang dihasilkan

\section{Prioritas Alternatif Strategi}

Prioritas strategi sebagai hasil analisis QSPM disajikan pada Tabel 4.

\section{Tabel 4.}

Hasil Analisis QSPM Industri Pemindangan Ikan Skala Sedang dan Besar

\begin{tabular}{lcc}
\hline \multicolumn{1}{c}{ Uraian Strategi } & TAS & Prioritas \\
\hline $\begin{array}{l}\text { Perluasan jaringan pemasaran melalui perantara bakul langganan untuk } \\
\text { melakukan promosi kepada bakul-bakul lain }\end{array}$ & 4,876 & II \\
$\begin{array}{l}\text { Penetrasi produk ikan pindang ke pasar-pasar modern untuk produk ikan } \\
\text { pindang yang mutu dan kualitasnya bagus }\end{array}$ & 4,753 & III \\
$\begin{array}{l}\text { Peningkatan kualitas produk ikan pindang dengan penerapan standar } \\
\text { kebersihan dan standar mutu produk }\end{array}$ & 4,390 & V \\
$\begin{array}{l}\text { Penerapan sistem manajemen modern pada industri ikan pindang dengan } \\
\text { peningkatan profesionalitas kerja, penguasaan teknologi dan pengetahuan } \\
\text { baru, pembenahan tata cara pemasaran, penjualan produk dan pengelolaan } \\
\text { keuangan }\end{array}$ & 4,522 & IV \\
$\begin{array}{l}\text { Peningkatan kinerja wadah perhimpunan pengusaha ikan pindang } \\
\text { sehingga dapat dibuat kesepakatan bersama tentang sistem manajemen } \\
\text { usaha industri ikan pindang dan standar produk yang layak jual }\end{array}$ & 4,948 & I \\
\hline
\end{tabular}

Sumber : Pengolahan data, 2014

Nilai TAS tertinggi 4,948 adalah strategi peningkatan kinerja wadah perhimpunan pengusaha ikan pindang sehingga dapat dibuat kesepakatan bersama tentang sistem manajemen usaha industri ikan pindang dan standar produk yang layak jual.

Kelompok gabungan pengusaha ikan pindang dapat berperan sebagai tempat/gudang informasi tentang teknologi terbaru bagi para pengusaha ikan pindang. Dengan peningkatan kinerja dan sosialisasi yang bersifat persuasif maka akan mendorong kesadaran dari pengusaha-pengusaha ikan pindang yang selama ini pasif dan cenderung kurang memperhatikan keberadaan wadah/kelompok gabungan ini. Selain itu, jika pengusaha-pengusaha ikan pindang dapat ditampung dalam 
sebuah wadah maka akan memudahkan pemerintah daerah (dinas terkait) untuk melakukan sosialisasi tentang temuan teknologi terbaru yaitu dengan cara mengumpulkan anggota kelompok sehingga penyampaian informasi dapat dilakukan secara bersamaan dengan tingkat pemahaman yang sama antara satu pengusaha dengan pengusaha lain.

Keikutsertaan atau partisipasi dengan menjadi bagian/anggota wadah/kelompok gabungan juga dapat berperan dalam pengaturan suplai bahan baku sehingga dapat menekan praktikpraktik persaingan tidak sehat antar pengusaha ikan pindang yaitu penimbunan bahan baku oleh salah satu pengusaha atau permainan harga bahan baku baik oleh bakul ikan ataupun oleh pengusaha sendiri maupun penyelesaian sengketa antara pengusaha dan pengusaha, antara pengusaha dan bakul bahan baku ikan atau antara pengusaha dan bakul pemesan ikan pindang. Manfaat lain dari menjadi anggota kelompok gabungan yaitu dalam hal pemerataan pemberian bantuan oleh pemerintah karena kelompok ini akan memberikan masukan kepada pemberi bantuan tentang pengusaha yang layak dan menjadi prioritas untuk diberikan bantuan tidak hanya akan diberikan kepada pengusaha yang sudah dikenal saja. selain itu, kelompok ini akan dapat membantu pengusaha penerima bantuan dalam hal pelaporan sehingga tidak akan menghambat atau mempersulit pemberi bantuan untuk memberikan laporan kerja pada tingkatan diatasnya (pimpinan).

\section{KESIMPULAN DAN SARAN}

\section{Kesimpulan}

Prioritas strategi pertama yaitu peningkatan kinerja wadah perhimpunan pengusaha ikan pindang sehingga dapat dibuat kesepakatan bersama tentang sistem manajemen usaha industri ikan pindang dan standar produk yang layak jual, dengan nilai TAS 4,948.

\section{Saran}

1. Bagi instansi terkait (Dislautkan, Disperindag, Bappeda, Pengusaha ikan pindang), perlu mengoptimalkan peran dari wadah koordinasi pengusaha ikan pindang dengan cara membentuk perwakilan ditiap kecamatan yang memiliki industri ikan pindang.

2. Bagi instansi terkait (Dislautkan, Disperindag, Bappeda, Pengusaha ikan pindang), perlu meningkatkan koordinasi dalam sistem pengelolaan industri ikan pindang melalui wadah/perhimpunan pengusaha ikan pindang yang sudah terbentuk sehingga dapt meminimalisir terjadi gesekan antar pengusaha ikan pindang.

\section{DAFTAR PUSTAKA}

Badan Pusat Statistik Provinsi Jawa Tengah. 2013. Jawa Tengah Dalam Angka 2012. Semarang.

David, M. E., Forest R. D. and Fred R. D. 2009. The Quantitative Strategic Planning Matrix (QSPM) Applied to Retail Computer Store. The coastal Business Journal, Vol 8 (1), 42-52.

Dinas Kelautan dan Perikanan Kabupaten Pati. 2014. Profil Pindang Pati. Pati.

Kamus Besar Bahasa Indonesia. 2014. Kamus Besar Bahasa Indonesia (KBBI) online_industri. http://kbbi.web.id. Diakses tanggal 20 Januari 2014.

Kementerian Kelautan dan Perikanan. 2012. Visi, Misi, Tujuan dan Sasaran Strategis. 
www.kkp.go.id/index.php/arsiplc/

8278/visi-misi-tujuan-dan-

sasaran-strategis/?category-

$i d=65$. Diakses tanggal 21 Januari 2014.

Lestyaningtyas, A. 2010. Analisis Komparatif Usaha Pengolahan Ikan Asin, Ikan Pindang dan Ikan Asap di Kecamatan Juwana Kabupaten Pati. Skripsi. Fakultas Pertanian. Universitas Sebelas Maret : Surakarta.

Media Penyuluh Perikanan Pati. 2013. Pengolahan Hasil Perikanan Dengan Pemindangan. http://media penyuluh perikanan pati.blogspot.com/2013/06/pengol ahan-hasil-perikanandengan.html. Diakses tanggal 20 Januari 2014.

Rangkuti, F. 1999. Analisis SWOT Teknik Membedah Kasus Bisnis. PT. Gramedia Pustaka Utama : Jakarta.
Undang-undang Republik Indonesia Nomor 45 Tahun 2009 tentang Perubahan Atas UU RI No. 31 Tahun 2004 Tentang Perikanan.

Wahyudi, J., Herna O. D. dan Slamet S. P. 2012. Formulasi Strategi Pengembangan Usaha Bandeng Presto (Studi di Kabupaten Pati). Prosiding Seminar Nasional Riset dan Kebijakan Sosial Ekonomi Kelautan dan Perikanan Tahun 2012. Jakarta. 127-137.

\section{BIODATA PENULIS}

Herna Octivia Damayanti, lahir 6 Oktober 1985 di kota Kudus Jawa Tengah. Pendidikan S1 Program Studi Oseanografi Jurusan Ilmu Kelautan Fakultas Perikanan dan Ilmu Kelautan Universitas Diponegoro tahun 2009. Saat ini bekerja sebagai Peneliti di Kantor Penelitian dan Pengembangan Kabupaten Pati. 